\title{
Developing Task-Based English Module for Secretary Students
}

\author{
Annisa Nur Fatimah ${ }^{1)}$, Dita Anggi Purbasari ${ }^{2)}$ \\ ${ }^{1}$ Polytechnic of Pratama Mulia (Annisa Nur Fatimah \\ email: anisa.nurfa@gmail.com \\ ${ }^{2}$ Polytechnic of Pratama Mulia (Dita Anggi Purbasari
}

\begin{abstract}
The secretary students of the college in which this research conducted use $B u k u$ Pegangan Kuliah (BPK) as learning resource of English subject. Nevertheless, according to the result of analysis, the book does not cover the criteria of a good book yet that are analyzed from seven aspects including objective, content, language skill, task, topic, methodology, and presentation. The materials which are presented in the book refer to general English and tend to emphasize on grammar. However, the secretary students need specific English material that focuses on the field. This study is aimed to (1) analyze the relevancy of the existing English textbook with the students' need; (2) describe the development of task-based English module for secretary department; (3) describe the validity of the module. This study is a research and development, which the main step is conducted in two ways. First, exploration includes library research and field research. Second, development includes product feature planning, product design, expert validation, and tryout. The specific English module is validated by an expert of teaching and learning English and an expert of secretary and office administration. The findings of the study are: (1) the materials of the existing book does not fulfill the secretary students' need yet; (2) designing task based English module for secretary students based on the data which are achieved from need analysis; (3) the result of module validation from the two experts obtains $87 \%$, it belongs to valid and feasible to be implemented in the teaching and learning.
\end{abstract}

Keywords: English for secretary; ESP; Need Analysis; R n D; Task Based Learning 


\section{INTRODUCTION}

Building communication to other people from over the world needs international language ability which almost people understand it as a tool of international communication. One of the international languages is English. Most of people in the world use English for communication in some fields such as education, business, trade, science and technology, profession etc. That is the reason why educational curriculum in Indonesia inserts English language as a compulsory subject that should be taught in school and college level.

It is in line with the government regulation related to general educations, which are called MKDU (mata kuliah dasar umum) that should be taught in college. The regulation is provided in UU number of 12, section of 35 , and subsection of 3, year of 2012 that mentions the general educations are religion, pancasila, civics, entrepreneurship, and English, and also other subjects which promote in developing character whether integrated or individual. While the curriculum of secretary department that has been arranged and approved by the chairman of the department putting English to be taught in five semesters. First semester is bahasa inggris 1 and second semester is bahasa inggris 2, both of them focus on Basic English. Third to fifth semester learn about ESP (English for specific purpose) which focuses on English for secretary. Those are should be taken in a series, it means the students who want to take bahasa inggris 2, they should complete bahasa inggris 1, and the students who take ESP class, they should

ELT- Lectura, Vol .6, No.2, August 2019 complete bahasa inggris 1 and bahasa inggris2 and so on.

The putting of English subject for secretary department of each semester in Polytechnic of Pratama Mulia is because considering the important of English as one of the students' skill that should be mastered. Furthermore, government also has a policy to put English as compulsory subject in high education for all discipline fields which is regulated in UU number 12, year of 2012. Teaching English for students of non- English department needs specific materials which are connected with the students' field. Therefore, an English lecturer should arrange specific English materials that are really applicable in the workplace. The material topic selected should be suited with student's field and need. Carter (1983) in Fauziati (2010, p. 109) identifies three types of ESP, English as a restricted language, English for academic and occupational purposes, and English with specific topics. The language used by air traffic controllers, accounting, secretary are examples of English as a restricted language.

Teaching and learning English should be taught to the students based on the students' need and level. It is important for an educator to understand students' needs so that the goal of the teaching and learning can be well obtained. In other hand, by knowing their needs, an educator also can arrange and implement the process of teaching and learning activities for achieving the learning goal. In line with it, according to the director of high education (direktur jendral pendidikan tinggi/DIKTI), in the foreword of high education regulation about the use of module which the news is 
uploaded in website of kopertis 12, Djoko Santoso (2013) mentions that a lecturer has duty to arrange lesson plan in detail, to write textbook, and hopefully it can be source of learning. The availability of lesson material and textbook encourage achieving the good quality of learning.

Material is one of learning components that has important role to support the teaching and learning success. It is the controller medium of teaching and learning activities. Material selection is conducted based on objective of department program, curriculum, syllabus, students' need, and level. A good material should demand of those aspects to create effective learning.

English becomes one of general and compulsory subjects for all departments in every college. Thus, the college students' need in learning English will be different, it is considered to the major that they take. The suitable English learning material for college students is ESP (English for specific purpose) since the materials represented in the teaching and learning will be based on the students' discipline. ESP material is more helpful for students to increase English ability based on the real context in the workplace. Budasi (2015, p. 1) states that English is as an International language which is not only taught in formal schools, but also in area of works, like in some of several companies. It makes studying English emphasize on two main purposes directing two main subjects: English for general purposes (EGP) and English for specific purposes (ESP).

ESP should meet the student's specified need and should make the learners learn something based on their reason for learning. ESP students are ELT-Lectura, Vol .6, No.2, August 2019 usually adult learners who already have some acquaintance with English and are learning the language in order to communicate a set of professional skills and to perform particular job related functions, Fauziati (2010, p. 107). In line with it, Cunningsworth (1995, p. 132) mentions that ESP materials meet learner's needs and that the language taught matches the language that the students will use. The material should take into account learner expectations and learning styles and should have clear role in the learning or teaching process.

This research was initiated when the researcher was asked teaching English in secretary class of Polytechnic Pratama Mulia. The researcher was a new lecture in that time and she should continue teaching English of secretary class by using the previous material. The researcher assumed that the teaching materials presented were still general. To collect the data, the researcher conducted textbook analysis to know the relevancy between topic and material which are provided in the textbook toward secretary field and students' need. The students' need is analyzed based on theoretical construct. The characteristics of good textbook are proposed by Ur (1996, p. 186), Skierso (1999) in Fauziati (2010, pp. 209-210), Byrd (2002, p. 417) in Fauziati (2010, pp. 210-211) dan Cunningsworth (1995, pp. 3-5), including objective, content, language skill, task or exercise, topic, methodology, presentation or format.

Implementing learning material in the class should be based on the procedures of certain learning method. It is as a guideline to help a lecture manage the running process of teaching and 
learning. Fauziati (2010, p. 211) mentions that materials which are appropriate for particular class need to have an underlying instructional philosophy, approach, method, and technique which suit the students and their needs. The textbook in this research will be based on task based learning. The selection of the method is based on the discussion with the collaborator lecturer that demands the students' interest in the teaching and learning process. Task based learning is kind of learning method which focuses on process and output. The materials are arranged and suited with the students' need in which they would be beneficial in the workplace. In addition, the materials also focus on language use. Hopefully, they can be able to apply the lesson in real communication. Fauziati (2014, p. 185) states that the activity of task based learning reflects real life and learners focus on meaning, they are free to use any language they want. Playing a game, solving a problem, or sharing information or experiences can all be considered as relevant and authentic task.

\section{a. Textbook Analysis}

Ur (1996, p.186) gives some criteria in assessing textbook. A good textbook should have: (a) objectives explicitly laid out in an introduction, and implemented in the material; (b) approach educationally and socially acceptable to target community; (c) clear attractive layout; print easy to read; (d) appropriate visual materials available; (e) interesting topics and tasks; (f) varied topics and tasks, so as to provide for different learner levels, learning styles, interests, etc; (g) clear instructions; (h) systematic coverage of syllabus; (i) content clearly organized and graded (sequenced by difficulty); (j) ELT- Lectura, Vol .6, No.2, August 2019 periodic review and test sections; (k) plenty of authentic language; (l) good pronunciation explanation and practice; (m) good vocabulary explanation and practice; (n) fluency practice in all four skills; (o) encourages learners to develop own learning strategies and to become independent in their learning; (p) adequate guidance for the teacher; not too heavy preparation load; (q) audio cassettes; (r) been readily avaliable locally.

Skierso (1999) in Fauziati (2010, pp. 209-210) mentions that pinpoints three main aspects to consider in selecting textbook. Those aspects represent the criteria of good textbook as follow: (a) language used in the textbooks should have correct, natural, recent, standard language. Vocabulary and grammar in the textbook should be controlled, especially for lower level students. It would be useful to have a variety genre so as to introduce students with different text of types; (b) the cultural information included in textbooks should be correct and recent, reflecting cultural of English. Visual aids are needed to help students understand cultural information; (c) the content of textbook should be useful, meaningful, and interesting for students. The general rules include: (1) material should be slightly higher in their level of difficulty than the students' current level of English proficiency; (2) they have clear instructional procedures and methods; (3) they have support for learning, ig: vocabulary lists, exercises which cover or expand on the content, visual aids etc.

According to Cunningsworth (1995, pp. 3-5) there are some criteria for evaluating a course book including aims and approaches, design and organization, language content, language skill, topic, 
methodology, teacher's book and practical consideration. In addition, Byrd (2002, p. 417) in Fauziati (2010, pp. 210-211) provides some questions as checklists to select textbook which fit with the students' needs which include: content or explanation, example, example or tasks, presentation or format.

Based on the explanation from some experts above, the researcher arranges the theoretical construct that is used to evaluate the existing textbook in the following table.

Table 1. The Criteria of Textbook Evaluation Based on Experts

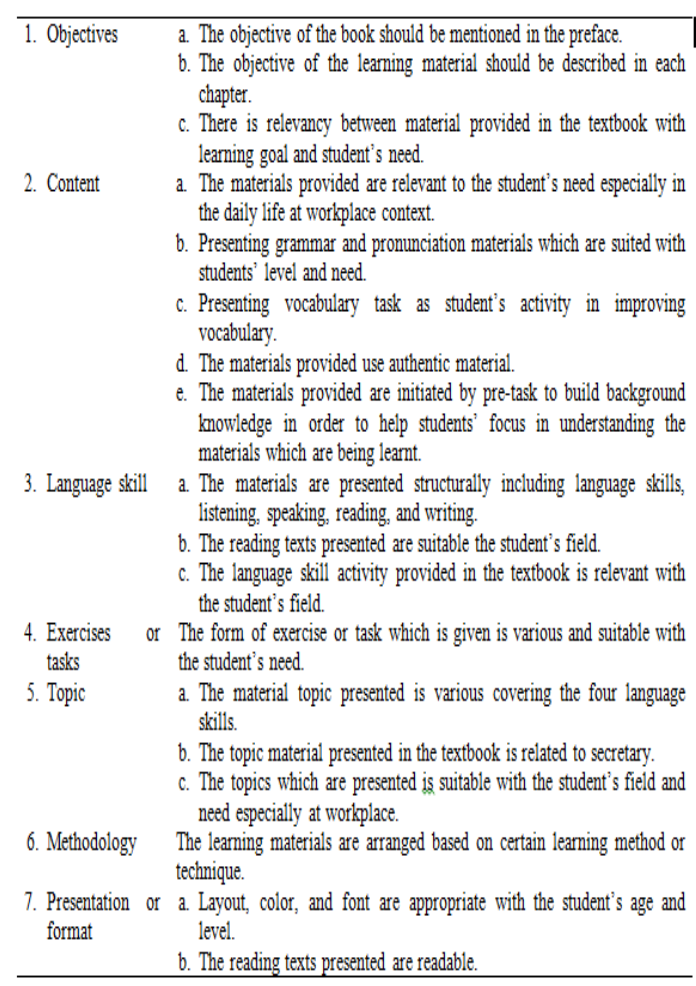

\section{b. Designing English Module for Secretary Students}

Designing teaching material is the process of selecting, adapting, and evaluating of teaching based specific terms of reference. Need analysis is very important before designing teaching materials for English specific purpose,

ELT- Lectura, Vol .6, No.2, August 2019
(Saragih, 2014, p.1). Based on the condition of the existing textbook, the researcher was initiated to design English module for secretary based on task based learning. The aspects in designing the module was based on the analysis result of the existing textbook and student's need, while the materials in the module were presented based on task based learning.

The advantages of task based learning method based on the research which is conducted by Shabani and Ghasemi (2014, p. 1719) are first, TBL is a meeting center methodology, i.e. it develops learners' communicative competence focusing on the meaning. Thus TBL encourages the learners to understand the written text with an unconscious and peripheral focus on the form of languages. Second, TBL is very helpful pre-task phase in which the teacher tries to activate the background knowledge and related schemata by engaging the learners in completing tasks similar which should be worked out during the task phase itself. TBL also has a more effective, authentic, meaningful and purposeful pre reading phase. Third, in TBL, there is post-task phase during which the teacher deductively teaches complicated formal aspects of language such as difficult structures, vocabulary, and other problematic points of the materials especially in reading text.

The objectives of this research are: (1) to describe the relevancy of the existing of English textbook with the students' need at secretary department; (2) to describe the development of task-based English textbook for secretary department; (3) to describe the validity of the English module for secretary. Based on the objectives of the research, the researcher 
would like to explain the condition of the existing textbook and design English module for secretary to fulfill the students' need.

\section{METHOD}

This research belongs to research and development. Research and development is kind of research that create a new product or develop an existing product to be better, it can be conducted in any field including education. Sugiyono (2014, p. 412) states $\mathrm{R}$ and $\mathrm{D}$ in educational context is aimed to improve educational productivity including increasing the number of qualifies students that are relevant to the needs of work industry. Some educational products such as specific curriculum for certain discipline, teaching method, teaching media, textbook, teaching module, evaluation system, etc.

The procedures of research and development are modified into two stages including exploration and product development, (Sukmadinata, 2006). Based on some considerations, the research was conducted in two stages, exploration, and product development. First, exploration stage includes doing need analysis of the students' need, evaluating the weaknesses of the existence of material book, doing library research, and doing field research such as class observation, doing interview to the lectures related to the learning materials and the teaching method, distributing questionnaire to the students for understanding more of the class situation, the learning materials and students' need, and the teaching method. Second, product development stage includes designing and validating the product, in this stage needs expert ELT- Lectura, Vol .6, No.2, August 2019 validator to validate the prototype, tryout the prototype module in the class, and the last is finishing draft. The subject of this research is the fourth semester students of secretary class in Polytechnic Pratama Mulia, the English lecture, and the material book which is dominantly used in the teaching and learning process. This research is conducted in secretary class of polytechnic Pratama Mulia Surakarta. Therefore, this research belongs to small scope since the English module for secretary is only tried out in one campus as subject sample of the research.

\section{Technique of data collection}

Techniques of collecting data in this research are: (1) document analysis, The researcher analyzes the existing English textbook which is used by the English lecture to know the strength and the weaknesses and also the relevancy of the material to the students' need, lesson plan, and curriculum; (2) interview, the researcher conducts interview to the English lecture and some secretary students of fourth semester, to know the strength and the weaknesses of the existing English textbook and the specific materials which are needed by the students based on their field; (3) questionnaire, the researcher distributes questionnaire to the students for gaining information such as the teacher's way in teaching, teaching and learning activity, the relevancy of the materials which are presented in the existing textbook, the description of the English materials that they need; (4) observation, the researcher conducts observation in secretary class of Polytechnic Pratama Mulia. The researcher analyzes the lectures and students' activities and the use of the 
existing textbook; (5) focus group discussion (FGD) is conducted after finishing try out. The participants of this activity are researcher, students, English lecture, and expert validator. This activity is to evaluate the situation during and after the prototype of module is used in the class.

\section{Technique of Data Analysis}

Qualitative data is analyzed through triangulation. The data gained from some sources are analyzed by using the model of Miles and Huberman (1994, p. 12) namely data reduction, data display, drawing and verifying conclusion.

Quantitative data is analyzed through percentage descriptive technique. The formula to analyze validation form and questionnaire is:

Information:

$$
P=\frac{x}{x i} \times 100 \%
$$

$\begin{array}{ll}\mathrm{P} & =\text { Percentage } \\ \mathrm{X} & =\text { Score obtained } \\ \mathrm{Xi} & =\text { Maximum score } \\ 100 \% & =\text { Constanta }\end{array}$

\section{FINDINGS AND DISCUSSION}

\subsection{Research Findings}

\section{a. Analysis of the existing book}

The exitinc book entitled 'Handbook of English 4 (for the students of secretary and business management). The title of each chapter in the textbook is about grammar material. Each chapter in the existing book does not cover the four of language skills structrally and coherently. The existing book does not present listening activity at all, there is also not available vocabulary and prononciation activity. Presentation of the materials in the existing book does not ELT-Lectura, Vol .6, No.2, August 2019 refer to certain learning method or technique. In the cover of the book written that the book is only for internal usage and it is used for English teaching and learning of secretary and management department. The summary of textbook analysis is presented in the table 2 .

Table 2. Analysis Result of the Existing Textbook

\begin{tabular}{|c|c|}
\hline Aspects & Findings \\
\hline Objective & $\begin{array}{l}\text { BPK belongs to general English therefore the materials are not suitable with the leaming } \\
\text { goal of English } 4 \text { subject and cannot fulfill the student's need. } \\
\text { BPK does not described in detail the specific objective of the leaming activities in each } \\
\text { chapter. }\end{array}$ \\
\hline Content & $\begin{array}{l}\text { BPK less provides vocabulary material. } \\
\text { BPK does not present vocabulary and pronunciation practice. } \\
\text { The leaming activities in the four skills do not have relation with the student's field. } \\
\text { The leaming materials in BPK are not belonged to authentic. }\end{array}$ \\
\hline $\begin{array}{l}\text { Language } \\
\text { skill }\end{array}$ & $\begin{array}{l}\text { The presentation of language in BPK is less structures and not proportional. Not each } \\
\text { chapter in BPK presents the four language skills. The language skill activities are less } \\
\text { authentic since they have no relation with the student's need. } \\
\text { BPK does not present listening activity at all. } \\
\text { BPK presents good grammar material however its presentation is less applicative in real } \\
\text { communication context especially at workplace. }\end{array}$ \\
\hline $\begin{array}{l}\text { Task or } \\
\text { Exercise }\end{array}$ & $\begin{array}{l}\text { BPK does not present various task since tasks is not given proportionally for the four } \\
\text { language skills in the BPK. }\end{array}$ \\
\hline Topic & $\begin{array}{l}\text { Topics provided in BPK are not relevant to develop the student's skill and leaming } \\
\text { experience. }\end{array}$ \\
\hline Methodology & $\begin{array}{l}\text { Arrangement of the leaming materials does not refer to certain leaming method or } \\
\text { technique. }\end{array}$ \\
\hline $\begin{array}{l}\text { Presentation } \\
\text { or format }\end{array}$ & The cover of the BPK cannot represent the content of the book. \\
\hline
\end{tabular}

Meanwhile, the researcher also collects the data through distributing questionnaire to the students about their assessment to the existing textbook. The result of the students' assessment is presented in the table 3 
Table 3. Students' Assessment to the Existing Textbook

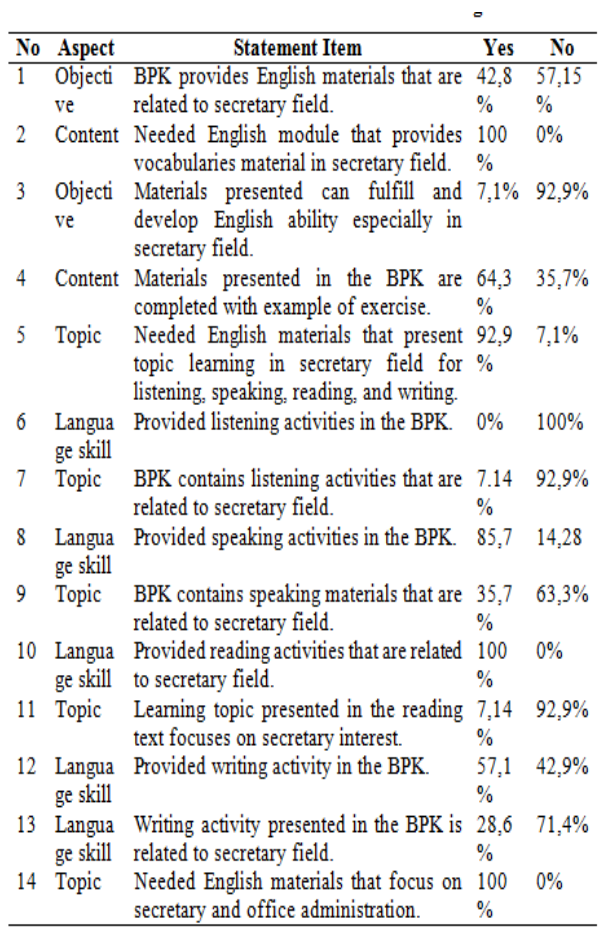

From the table 3 above, it can be concluded that the existing book cannot fulfill the need and the study background of secretary students. The students need a module that presents English materials which the topic is related to secretary and office administration, and covers English language skills including listening, speaking, reading, and writing. The students also hope a module that provides various activities of language components which are not only the four language skills but also others such as vocabulary, grammar, and pronunciation.

\section{b. Need Analysis}

Before designing material of Task Based English module for secretary, the researcher was conducted need analysis, through doing interview with the secretary students to know the significant of the use of the existing textbook (BPK) during teaching and learning, whether the BPK covers the four language skills activities or not. Interview with the collaborator is to know whether there is needed English textbook development for secretary students, kind of materials that is suitable to fulfill the students' need, and kind of learning method that can be used to arrange the materials in the module development. Interview with the lecturer of secretary department is to know English materials that are appropriate to the students' need. Interview with the chairman of secretary department is to know the curriculum of secretary department; the goal of English subject which is given in secretary department, the expectations after the students learn English, and the materials that are suitable and applicable for the students at workplace. Class observation and distributing questionnaire are also done to know the use of BPK in the class, and distributing questionnaire to know the students' characteristics, want, and need related to the material. The following table is the sample data of need analysis of students' questionnaire.

Table 4. Sample Data of Need Analysis of Students' Questionnaire

\begin{tabular}{|c|c|c|c|c|}
\hline Aspect & Indicator & Item & Percentage & Data \\
\hline $\begin{array}{l}\text { Present } \\
\text { situation }\end{array}$ & $\begin{array}{l}\text { Students' reason and } \\
\text { hope by joining English } \\
\text { class. }\end{array}$ & 3 & $\begin{array}{l}16(100 \%) \\
11(68,8 \%) \\
2(12,5 \%)\end{array}$ & $\begin{array}{l}\text { Communication } \\
\text { in English. } \\
\text { Writing text in } \\
\text { English. } \\
\text { Others }\end{array}$ \\
\hline $\begin{array}{l}\text { Target } \\
\text { situation }\end{array}$ & $\begin{array}{l}\text { Relevancy between } \\
\text { materials taught with } \\
\text { the students' need and } \\
\text { want. }\end{array}$ & 21 & $\begin{array}{l}13(81,3 \%) \\
3(18,8 \%)\end{array}$ & $\begin{array}{l}\text { Relevant } \\
\text { Irrelevant }\end{array}$ \\
\hline $\begin{array}{l}\text { Learning } \\
\text { situation }\end{array}$ & $\begin{array}{l}\text { Quality of materials in } \\
\text { BPK. }\end{array}$ & 22 & $\begin{array}{l}3(18,8 \%) \\
13(81,3 \%)\end{array}$ & $\begin{array}{l}\text { Materials are } \\
\text { structured well. } \\
\text { Materials are } \\
\text { unstructured well. }\end{array}$ \\
\hline
\end{tabular}

\section{b. Product Feature Planning}

The selection of topic materials are based on description of learning outcomes of special skills that are charged to the subject and based on advices from the 
collaborator, the lecturer of secretary and the chairman of secretary department.

Table 5. Topic Materials Based on Need Analysis

\begin{tabular}{cl}
\hline \multicolumn{1}{c}{$\begin{array}{c}\text { Language } \\
\text { Skills }\end{array}$} & \multicolumn{1}{c}{ Topic } \\
\hline Listening & $\begin{array}{l}\text { Listen monologue and dialogue about journey and work agenda, } \\
\text { kind of documents and other equipment needed, business } \\
\text { negotiation, and understand content of monolog and dialogue by } \\
\text { finding main idea, detailed information for both explicit and } \\
\text { implicit from the audio. }\end{array}$ \\
Speaking & $\begin{array}{l}\text { Express asking and giving utterance, guiding colleague and client, } \\
\text { report of new client, report of product selling. }\end{array}$ \\
Reading & $\begin{array}{l}\text { Read descriptions text that are related to secretary field, then } \\
\text { understand its content by finding main idea, reference, word }\end{array}$ \\
& $\begin{array}{l}\text { utterance, and detailed information for both explicit and explicit } \\
\text { from the text. }\end{array}$ \\
Writing & $\begin{array}{l}\text { Write plan of official journey and arrangement of chief's agenda, } \\
\text { email and proposal letter by using appropriate vocabularies, } \\
\text { grammar, and organization. }\end{array}$ \\
\hline
\end{tabular}

The materials of English module for secretary were presented based on the procedure of task based learning. The determination of the learning method is based on the result of interview with the collaborator which is suited with characteristic and learning target of the secretary's students. Willis (1999) in Fauziati (2014, p. 187) presents a three stage phases: (1) pre-task (introduction to the topic and task); (2) task (task, planning, and report); (3) language focus or post-task (analysis of task).

\section{c. Designing Product}

The product is 'Task Based Learning: English for Secretary' which is arranged for the fourth semester of secretary's students. The product is designed based on the result of need analysis and seven aspects of the criteria of good material and textbook which are constructed from experts, namely objective, content, language skill, task or exercise, topic, methodology, and presentation or format. The materials are presented based on task based learning procedure. The product is tried out to the fourth semester of

ELT- Lectura, Vol .6, No.2, August 2019 secretary students of Polytechnic Pratama Mulia. Because of the limited time allocation, the product is only tried out in one college.

\section{(1) Validity}

Before the prototype of task based English textbook is tried out in the teaching and learning process, the prototype is validated by two experts to know content validity and feasibility of the prototype. The first validator is an expert at English teaching and learning, while the second validator is an expert at secretary and office administration. The result of the expert validation is presented in the following.

Table 6. Result of Expert Validation through the English Module

\begin{tabular}{|l|c|c|c|c|c|c|}
\hline \multicolumn{1}{|c|}{ Aspects } & Score & Score Max & $\mathbf{\%}$ & Score & Score Max & \% \\
\hline Objective & 3 & 4 & 75 & 3 & 4 & 75 \\
\hline Content & 14 & 16 & 88 & 14 & 16 & 88 \\
\hline Language skill & 16 & 16 & 100 & 13 & 16 & 81 \\
\hline Exercise or task & 15 & 16 & 94 & 15 & 16 & 94 \\
\hline Topic & 10 & 12 & 83 & 9 & 12 & 75 \\
\hline Methodology & 4 & 4 & 100 & 3 & 4 & 75 \\
\hline Presentation or format & 3 & 4 & 75 & 3 & 4 & 75 \\
\hline Total & 65 & 72 & $90 \%$ & 60 & 72 & $83 \%$ \\
\hline $\begin{array}{l}\text { Range score of two } \\
\text { validators }\end{array}$ & \multicolumn{7}{|c|}{$87 \%$} \\
\hline $\begin{array}{l}\text { Percentage of range } \\
\text { score of two validators }\end{array}$ & \multicolumn{7}{|c|}{63} \\
\hline
\end{tabular}

Table 6 showed that the first expert scored $90 \%$, the second expert scored $83 \%$, while the percentage of range score from the two validators is $87 \%$. It belongs to valid and ready to be implemented in the class, since according to Arikunto (1996, p.224) mentions that the score of a product in between $76 \% \leq$ skor $\leq 100 \%$, the product categorizes valid and ready to be tried out.

\section{(2) Try Out of the Prototype Module}

Tryout of the prototype module is implemented in three times to know feasibility of the product, whether the prototype can be used well by the students in the process of teaching and learning or not. After doing tryout, the researcher 
conducted focus group discussion to reach the students' and the collaborator' advices and revisions related to the prototype. In the end of the tryout cycle, the researcher also distributed questionnaire as the form of the students' and collaborator's evaluation about the prototype module. The result of the FGD and questionnaire were used to consider in revising the final product.

\section{First tryout}

The result of FGD after conducting the first tryout, first is the collaborator advised in order to change the city names provided in the materials of task based English module by using names of international city, or names of national city that become business center in Indonesia. In other hand, the collaborator also advised the presentation of the material. He said chapter three ' 'equipment and materials in the office' should be put in the initial of the learning as chapter one since according to him, secretary's equipment, and materials should be introduced and taught earlier. Both of the collaborator and students state that the instruction of the tasks is clear, there are no instructions needed to be changed. The students also argued that the tasks are in the level of medium, some learning tasks such as vocabularies building can help the students to learn new terms. They also argued that the materials presented are related to secretary field. However, a student delivered her opinion so that the researcher added phonetic symbol for each word in the vocabularies building activity. She argued that the material can help them to know and practice correct pronunciation.

ELT- Lectura, Vol .6, No.2, August 2019

\section{Second tryout}

After doing FGD in the second tryout, there is no advice or revision from both the collaborator and the students. According to them, the materials, speaking, and reading taught in that session were good enough and could fulfill the students' need. The students argued that instructions in the tasks are clear and understandable. The difficulty of level of the materials is medium. They also stated that they had gained something new during trying out one and two such as getting new vocabularies and learning pronunciation.

\section{Third tryout}

In the third FGD, there is no significant advice and revision from both the collaborator and the students. The advice came from a student in the point format of table in task 11 in writing activity, she argued in order to add two columns more in the table for mentioning place of agenda and documents needed. In other hand, they mentioned that the materials are good enough, and relevant to the students' field. They stated that the English module could be used as teaching and learning reference in the next learning. Furthermore, they had opinion that instructions in the tasks are understandable. The students also delivered opinion that the learning materials in that session belong to medium, not too difficult and not too easy.

In the end of tryout cycle, the researcher also distributed questionnaire to the collaborator and the students to evaluate the task based English module for secretary. The result of the collaborator's evaluation was $92 \%$, it showed that the module categorized valid 
and feasible. While, the result of the students' evaluation was $94 \%$, it showed that the designing of task based English module for secretary was suited with the students' need and want. It also means the task based English module for secretary is feasible to be implemented in the class.

\subsection{Research Discussion}

This research is initiated by doing need analysis before designing learning module. It is important to do since it can be used to consider for selecting materials that are suitable to the students' need. Applying authentic material in teaching and learning can help students to practice communication in real context. In line with Flowerdew (2013, p. 231) states that need analysis, carried out to establish the 'what' and the 'how' of a course, is the first stage in ESP course development, followed by curriculum designs, material selection, methodology, assessment and evaluation. However, these stages could not be seen as a separate, proceeding in a linier fashion.

Furthermore, deciding a learning method should be done before designing module, since learning method is as a procedure in presenting materials in the module. The selection of learning method is based on students' character and need. Based on interview with the collaborator and distributing questionnaire to the students, it can be analyzed that the appropriate method to be implemented is task based learning. Fauziati (2014, p. 185) states that the activity of task based learning reflects real life and learners focus on meaning, they are free to use any language they want. Playing a game, solving a problem, or sharing information or experiences can all be considered as relevant and authentic task.
The other advantage of task based learning is it supports to use authentic material that can create learning such as in real context and it also can attract the students to explore their background knowledge before learning the material. It is in line with the research finding from Shabani and Ghasemi (2014, p. 1719) task based learning is very helpful pre-task phase in which the teacher tries to activate the background knowledge and related schemata by engaging the learners in completing tasks similar which should be worked out during the task phase itself. Task based learning also has a more effective, authentic, meaningful and purposeful pre reading phase.

\section{CONCLUSION}

Book is one of the teaching and learning components that has important role to achieve the success of teaching and learning activity. A good book should provide learning materials and activities that are suitable with students' need. However, the analysis result of the existing textbook in this research does not fulfill the students' need. In general the content of the textbook focuses on grammar and general English. The presentation of four language skills in the existing book is also not proportionally available in each chapter. The textbook does not provide listening material at all. There is also no vocabularies building and pronunciation activity. Furthermore, the topic materials of the existing textbook are irrelevant with secretary field.

There is needed an English module that focus on secretary students to support effective teaching and learning process. To help in obtaining the learning goal of English subject of secretary students, the 
researcher designed a task based English module for secretary which is suited with the students' need. The module was designed based on the result of need analysis, analysis of syllabus and the goal of secretary study program. The topic selection presented in the module is suited with the description of learning outcome on specific skills which is charged to English subject, and also based on advices that are achieved from lecturer of secretary department, the chairman of secretary department, and the collaborator.

After finishing in designing English module, the next step is expert validation toward the module. In this case, the experts that were invited to validate the module are lecturer who is expert in English learning and ESP research and lecturer who has old experience in teaching secretary. The result of the module validation from the two experts is 63 , in percentage is $83 \%$. The score belongs to valid and it can be tried out in the class.

The module was tried out for three times, and because of the limited time, the module was only implemented in one college. In the end of the tryout session of meeting, there were focus group discussion among researcher, collaborator and secretary students to discuss about strength and weaknesses during the module was used in the class. The collaborator and the students' comments and advices were used to revise the module. In these session, the collaborator delivered advices about presentation of the module, he asked the researcher to switch position between chapter one and two. According to him, the learning material of first chapter in the module should be presented in first chapter since ELT-Lectura, Vol .6, No.2, August 2019 it is important to be introduced to the students in the initial learning. He also advised the researcher to change the names of local city which is available in the module with the names of international city or local city that becomes business and trade center.

In addition, especially in the end of third meeting the researcher also distributed questionnaire to the collaborator and the students to know their opinion and perception toward the module during it was implemented in the class. In this session, there was no significant advice from both collaborator and students. There was also no essential revision from both of them. Thus, the module designed belongs to feasible to be implemented in the class.

\section{REFERENCES}

Arikunto, Suharsimi. 1996. Prosedur Penelitian Suatu Pendekatan Praktek. Jakarta: Rineka Cipta.

Budasi, I Gede. 2015. English for specific purpose. Yogyakarta: Graha Ilmu Press.

Cunningsoworth, Alan. 1995. Choosing your course book. Oxford: Mackmillan Publisher Limited.

Direktur Jendral DIKTI. 2013. MKDU diPerguruan Tinggi. Unknown Publisher.

Fauziati, Endang. 2010. A Teaching English as a foreign language (TEFL). Surakarta: Era Pustaka Media Press.

Fauziati, Endang. 2014. Methods of teaching English as a foreign language (TEFL): Traditional Method, Designer Method, Communicative Approach, Scientific Approach. Surakarta: Era Pustaka Media Press. 
Flowerdew, Lynne. 2013. The handbook of English for Specific Purposes: Need Analysis and Curriculum Development in ESP. First Edition. : John Wiley and Sons, Inc.

Miles, M. B., and Huberman, A. M. 1994. Qualitative Data Analysis: An Expanded Sourcebook (Second Edition). California: Sage Publication.

Saragih, Erikson. 2014. Designing ESP Materials for Nursing Students Based on Need Analysis. International Journal of Linguistics. 6 (4): 1948-5425.

Shabani, M., Ghasemi, A., 2014. The Effect of Task-Based Language Teaching (TBLT) and Content Based Language Teaching (CBLT) on the Iranian Intermediate ESP Learners' Reading Comprehension. International journal of Social and Behavioral Sciences. 98 (-): 17131721.

Sugiyono. 2014. Metodologi Penelitian Kuantitatif, Kualitatif, $R \quad \& \quad D$. Bandung: Alfabeta Press.

Sukmadinata, S, Nana. 2006. Metode Penelitian Pendidikan. Bandung: Remaja Rosda Karya.

Undang-Undang Republik Indonesia Nomor 12 Tahun 2012 Tentang Mata Kuliah Dasar Umum yang Diajarkan diPerguruan Tinggi.

Ur, P. 1996. A Course in Language Teaching: Practice and Theory. Cambridge: Cambridge University Press. 